\title{
QUANTITATIVE MEASUREMENT OF THE LEATHER DEGREE OF SWELLING
}

\author{
SIMONA POPA ${ }^{\mathrm{a}}$, SORINA BORAN ${ }^{\mathrm{a}, *}$
}

\begin{abstract}
In this paper are presented the experimental results obtained in assessing the degree of swelling of the leather by means of shrinkage temperature. The moisture content of the skin was determined in its various processing steps, correlated with the leather shrinkage value.
\end{abstract}

Keywords: drying process, skin type, shrinkage temperature

\section{INTRODUCTION}

During processing of the animal skin there are stages that change the internal protein structure of the collagen fibers [1-5]. Rheology of collagen films is presented in [6].

Some of the stages have a pollutant effect on the environment. To reduce the negative effects of industrial activities on the environment can be used the following solutions: recycling some of the poluating materials [7-9], obtaining other useful products by reusing wastes [10-11] or to immobilize other hazardous waste [12-13].

In industrial technologies, for assessing the degree of leather processing, there are still only qualitative assessments, such as: craving, elasticity, softness etc. [1-4]

From the best of our knowledge, the introduction of quantitative parameters for characterizing the different stages of the process is not yet accomplished.

The present paper attempts to explore one of the few quantitative parameters for characterizing the degree of leather licking, namely: the shrinkage temperature, using the drying operation.

a Faculty of Industrial Chemistry and Environmental Engineering, University Politehnica Timisoara, Victoriei Sq.2, 300006 Timisoara, Romania

*Corresponding author: sorina.boran@upt.ro 
Drying of colloidal materials is a process of heat and mass transfer, usually accompanied by the deformation processes of the material [14].

The shrinkage temperature characterizes the degree of crosslinking of the collagen fibers, by determining the resistance of the dermal tissue to the heat and humidity action. It represents the temperature at which the shortening of the dermal tissue fibers begins to occur in the aqueous medium when raising the temperature [4].

The shrinkage temperature of the finished skins is influenced by several factors, including the water content of the skin.

Quantatively, it is expected that the contraction temperature will vary inversely with the degree of swelling of the skin, with its non-reticulation. The moisture content of the skin may be calculated using the following relationship [15-17]:

where: $m_{i}-$ initial leather mass, $g$

$$
U, \%=\frac{m_{i}-m_{d}}{m_{d}} \cdot 100
$$

$m_{d}-$ dried leather mass, $g$

The aim of the paper is to correlate the degree of swelling of the dermis expressed by the shrinkage temperature with the moisture content using the drying process of the skin samples from different stages of leather production.

\section{RESULTS AND DISCUSSION}

By drying in an oven at $100^{\circ} \mathrm{C}$ of the skins, their weight will decrease over time. In Table 1 are presented the weight of the skins at different stages of processing at different drying times

Table1. The weight of the skins at different stages of processing at different drying times

\begin{tabular}{|c|c|c|c|c|c|}
\hline \multirow{2}{*}{ No. } & Time, & \multicolumn{4}{|c|}{ Weight depending on skin type, g } \\
\cline { 3 - 6 } & $\min$ & Soaked & Gelatine & Pickled & Tanned \\
\hline 1 & 0 & 23.8 & 23.8 & 23.8 & 23.8 \\
\hline 2 & 60 & 15.1 & 7.6 & 10.47 & 8.23 \\
\hline 3 & 120 & 10.9 & 4.43 & 6.95 & 4.7 \\
\hline 4 & 180 & 7.2 & 2.95 & 5.48 & 4.7 \\
\hline 5 & 240 & 7 & 2.8 & 5.4 & 4.7 \\
\hline 6 & 300 & 7 & 2.8 & 5.4 & 4.7 \\
\hline
\end{tabular}


Analysing these values it is found that the drying processes of different skin types have a similar evolution. The most water is eliminated by drying at the beginning of the process, this being the existing water between the fibers, then by diffusion from the inside of the fibers outwards, and eventually the removing it completely from the skin.

The gel material, i.e. the soaked skin, gelatin and pickled ones, dries slower because the water is strongly retained inside it. The fastest drying process appears for the tanned skin (the fibrous body).

The equations of the mass loss curves of the skins at different stages of processing at different drying times are presented in Table 2.

Table 2. The equations of the mass loss curves of the skins at different stages of processing at different drying times

\begin{tabular}{|c|c|c|}
\hline Skin type & $y=a x^{2}-b x+c$ & $R^{2}$ \\
\hline Soaked & $y=0,0003 x^{2}-0,1419 x+23,375$ & 0.992 \\
\hline Gelatine & $y=0,0004 x^{2}-0,1714 x+22,133$ & 0.939 \\
\hline Pickled & $y=0,0005 x^{2}-0,1874 x+21,524$ & 0.896 \\
\hline Tanned & $y=0,0005 x^{2}-0,1961 x+21,571$ & 0.918 \\
\hline
\end{tabular}

On the basis of these results it was possible to determine the decrease in time of the water content for the respective skins, values shown in Table 3.

Table 3. The water content at different stages of processing at different drying times

\begin{tabular}{|c|c|c|c|c|c|}
\hline \multirow{2}{*}{ No. } & Time, & \multicolumn{4}{|c|}{ The water content at different stages of processing, \% } \\
\cline { 3 - 6 } & min & Soaked & Gelatine & Pickled & Tanned \\
\hline 1 & 0 & 70.6 & 88.23 & 77.31 & 80.25 \\
\hline 2 & 60 & 34 & 20.2 & 21.3 & 14.8 \\
\hline 3 & 120 & 16.4 & 2.65 & 6.51 & 0 \\
\hline 4 & 180 & 0.84 & 0.63 & 0.34 & 0 \\
\hline 5 & 240 & 0 & 0 & 0 & 0 \\
\hline
\end{tabular}

The equations of the water content of the skins at different stages of processing and different drying times are presented in Table 4. 
Table 4. The equations of the water content curves of the skins at different stages of processing at different drying times

\begin{tabular}{|c|c|c|}
\hline Skin type & $y=a x^{2}-b x+c$ & $R^{2}$ \\
\hline Soaked & $y=0,0013 x^{2}-0,5895 x+68,606$ & 0.987 \\
\hline Gelatine & $y=0,003 x^{2}-1,0426 x+83,024$ & 0.957 \\
\hline Pickled & $y=0,0024 x^{2}-0,8642 x+73,319$ & 0.967 \\
\hline Tanned & $y=0,0029 x^{2}-0,986 x+74,884$ & 0.946 \\
\hline
\end{tabular}

By determining the shrinkage temperature in the skins of the various manufacturing steps, the results presented in Table 5 are obtained.

Table 5. The skin shrinkage temperature of the different stages of manufacture

\begin{tabular}{|c|c|c|c|c|}
\hline \multirow{2}{*}{ No. } & \multicolumn{4}{|c|}{ The shrinkage temperature of different skin type, ${ }^{\circ} \mathbf{C}$} \\
\cline { 2 - 5 } & Soaked & Gelatine & Pickled & Tanned \\
\hline 1 & $62.5-66.5$ & $52-58$ & $49.5-53$ & $89-92$ \\
\hline
\end{tabular}

It is found that the highest shrinkage temperature occurs in tanned leather, which is a fibrous material.

The other forms of leather processing (soaked, gelatin, and pickled) refer to gel bodies, which can be transformed by incorporating water to the sol-gel.

This also explains the variation in the shrinkage temperature of these skins depending on their moisture content, which also results from the analysis of the graph in Figure 1.

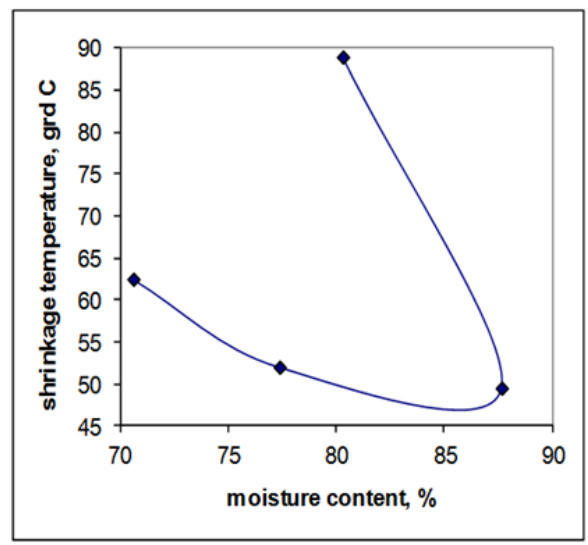

Figure.1. Dependence of shrinkage temperature on skin moisture content 


\section{CONCLUSIONS}

As the skin sprouting progresses, the gelling components are eliminated, leaving only the fibrous material (collagen fibers) which is more resistant and determines the characteristics of the leather, in our case, the shrinkage temperature, which is the greatest for the tanned skin.

The works have shown that the shrinkage temperature cannot alone assess the state of the fibrous material, due to the massive gel matrix at the beginning of the processing.

Determinations made on various processed materials indicate a qualitative correlation between the shrinkage temperature and the degree of crosslinking of the collagen material, which gives mechanical strength to the leather.

\section{EXPERIMENTAL SECTION}

In order to determine skin moisture, STAS 8574/70 was worked out, taking skin samples of the same weight from different skin processing steps, namely: soaked skin, gelatin skin, pickled skin and tanned leather.

They were placed in the oven at $100^{\circ} \mathrm{C}$ for water evaporation, weighing periodically until a constant mass was reached.

Determination of the shrinkage temperature is performed, according to STAS 5053/70, by means of a device which allows tracking of the moment when the skin contraction occurs on a graduated dial.

The temperature at which the indicator needle deviation occurs is the skin's shrinkage temperature. Usually there is a temperature range in which the skin contraction occurs.

\section{REFERENCES}

1. F.O'Flaherty, W.T. Roddy, R.M. Lollar (Ed.), „The Chemistry and Technology of Leather", Vol.I., Krieger Publishing Company, Malabar, Florida, 1979.

2. K. Bienklewicz, „Physical Chemistry of Leather Making”, R.E. Krieger Publishing Company, Malabar, Florida, 1983.

3. G. Chiriţă, „Tehnologia Pieilor şi Blănurilor”, Vol.I, Ed.Tehnică, Bucureşti, 1985.

4. E. Heidemann, „Fundamentals of Leather Manufacture”, Roetherdruck, Darmstadt, 1993. 
5. J.H. Sharphouse, „Leather Technician's, Handbook”, Leather Producers' Association, Northhampton, 1995.

6. S. Popa, S. Boran, V. Simulescu, Materiale Plastice, 2017, 54, 359.

7. G. Mosoarca, P. Negrea, M. Motoc, M. Craciunescu, M. Anghel, D. David, Rev. Chim. 2009, 60, 636.

8. G. Mosoarca, V. Pode, Rev. Chim. 2009, 60, 836.

9. G. Mosoarca, P. Negrea, Journal of Environmental Protection and Ecology, 2012, 13, 198.

10. I. Lazau, C. Vancea, Romanian Journal of Materials, 2012, 42, 270.

11. C. Vancea, I. Lazau, Central European Journal of Chemistry, 2014, 12, 804.

12. I. Lazau, C. Vancea, G. Mosoarca, Romanian Journal of Materials, 2013, 43, 210.

13. C. Vancea, G. Mosoarca, A. Negrea, A. Latia, R.M. Jurca, Romanian Journal of Materials, 2016, 46, 296.

14. V.A. Sychevskii, International Journal of Heat and Mass Transfer, 2015, 85, 740.

15. E.A. Bratu, „Operaţii unitare în ingineria chimică”, vol.II., Ed. Tehn., Bucureşti 1985.

16. A. Dăscălescu, „Uscarea şi aplicaţiile ei industriale”, Ed. Tehn., Bucureşti 1974.

17. F. Vitan, N. Badea, M. Macoveanu, I. lacomi, „Ingineria proceselor în textile şi pielărie", Casa de presă şi Editura Cronica, laşi 1992. 